\title{
Photoessay
}

11. Seeing the wood

\section{for the trees:}

\section{Media coverage of the}

Ngatihine Forestry Block

\section{legal dispute $1976-8$}

IOHN MLLER

\section{ABSIRACI}

The first Nga Tamatoa protest at Waitangi in 1971 launched a new era of assertiveness in the struggle for Māori Treaty, land, and cultural rights. Such events as the Māori Land March (1975) and the occupations at Bastion Point and Raglan (1978) received prominent treatment in mainstream media of the day. However, how well equipped were the then predominantly monocultural news organisations to understand underlying issues behind such protests? Four decades on, media commentators have observed the propensity of majority culture media structures to frame their treatment of such events through their own cultural constructs and ignore crucial social, cultural and historical factors that ought inform a more thorough and relevant coverage of such minority culture issues. Although not achieving the same degree of prominence in the media as these other cases, the Ngatihine Land/Forestry legal dispute in Northland, New Zealand, in 1976-8 exposed the inabilities of the media at that time to adequately see past cultural 'blind spots' (Morgan, 2009) and take into account important historical and sociological factors in their reportage on this issue. This was something that non-mainstream media were more comfortable with 
doing. This article examines how the participants in this struggle had to first discover this necessity themselves and then present these frameworks to the media in order to encourage them to produce a more relevant coverage of this land dispute.

Keywords: culture, development communication, framing, indigenous, land rights, Māori, Ngatihine

TN HER address at AUT University in May 2007, Professor Arlene Morgan from the Columbia Graduate School of Journalism challenged journalists to see past what she described as 'blind spots' and report with authentic voice and integrity. She called on them to 'do the right story' by going beyond their own assumptions, and ensuring that, for minority groups, their reporting was inclusive and accurate. Their work should fill in 'knowledge gaps' and bring about greater understanding of matters concerning minority cultures that the wider community was not previously aware of. (2009, p. 98). The word 'right' might normally be very subjective but in this article I take its use here to mean a story that features its subjects in a way that takes into consideration Professor Morgan's expressed concerns.

Sue Abel and others have observed how the media defined social problems and influenced the reactions of policymakers' reactions while ignoring the influence of historical-social contexts such as colonialism. This influenced the discourse around Māori crime or education. Dr Abel recognised that all this is not necessarily deliberate or that journalists are racist, when in a 2010 public lecture, she commented on

...the sheer power and longevity of the dominant media's way of framing issues and events. This can be so powerful that it becomes commonsense, and it is hard for those of us not actually involved in the event to frame it any other way (Abel, 2010).

The first Nga Tamatoa protest at Waitangi in 1971 launched a new era of assertiveness in the struggle for Māori Treaty, land, and cultural rights. Such events as the Māori Land March (1975) and the occupations at Bastion Point and Raglan (1978) received prominent treatment in mainstream media of the day. However, how well equipped were the then predominantly monocultural news organisations to understand underlying issues behind such protests? Four decades on, media commentators have observed the propensity 176 PACIFIC JOURNALISM REVIEW 17 (1) 2011 
of majority culture media structures to frame their treatment of such events through their own cultural constructs and ignore crucial social, cultural and historical factors that ought to inform a more thorough and relevant coverage of such minority culture issues.

My own interest in issues of media coverage comes from an involvement in a complex legal dispute over a Māori-owned land block 35 years ago, during which I had much contact with journalists of the day, at a time when the media landscape was much less ethnically diverse. Of the 41 or so 'mainstream' journalists I had varying contact with over a 24 month period from 1976 to 1978, 36 were Pakeha, three were Māori (one of these a trainee) and two were Samoan. ${ }^{1}$ I was effectively presenting a minority culture issue to media workers overwhelmingly of the majority culture. I discovered that the subject was virtually unknown territory to these journalists. This was certainly a 'blind spot' issue.

The site of the actual dispute was the Ngatihine Block, a 5500 ha amalgamation of more than 70 separate Māori land titles in the heartland of the Ngatihine people of mid-Northland. The land, covered in secondary growth bush with remnant pockets of native forest, was mostly unused and sizeable back rates were owed to the local county council. The lack of active, hands-on management by the owners themselves was a legacy of 19th century colonialist land legislation. This system was implemented from 1865 onwards by the Native Land Court, described by the late Dr Hugh Kawharu in 1977 as '...a veritable engine of destruction for any tribe's tenure of land anywhere' (1977, p. 15).

Traditional tribal stewardship of land was replaced with European ownership concepts, which eased the land's sale to the colony's settlers. The less appealing, poorer quality land that survived into the 20th century was passed down to increasing numbers of descendents as shares were split and divided among them (Webster, 1975, p. 135). Land under this system became more vulnerable to lease or sale. The response of officialdom was not to remedy these deficiencies to encourage a more active and involved ownership group. Instead, legislators established a new status quo of proxy decision making frameworks, such as s.438 of the 1953 Maori Affairs Act, which placed into the hands of a Court-appointed trust board '... all such powers and authorities as are necessary for the effective performance of the trusts'. Any person could be appointed as a trustee, whether or not they were owners or even Māori. These historical-social situations informing the 'Māori narrative' provide the 
background to this story. However, it was a context not generally acknowledged by the news media. A salient approach to defining history through an indigenous perspective on news is the Todorov five stages of narrative model. According to Todorov (cited by Stuart, 2002, p. 49), every narrative begins with a status quo:

Stage two is a disruption to that that status quo, followed by stage three, a deterioration of conditions. Stage four is a working through the issues to a resolution and stage five is the restoration of the status quo, or the establishment of a new status quo.

Using Todorov's model as a benchmark, these historical situations represent the 'disruption' and the 'deterioration' phases of the Māori narrative (cited by Stuart, p. 51).

In the case of the Ngatihine lands, the potential threat of charging orders from the local Bay of Islands County Council over unpaid rates activated earlier proposals to join up the many titles. In anticipation of this, its rating officer, a shareholder in some of the blocks, canvassed forestry sector interest in 1971, in an attempt to produce some development income from the land. After plans were presented to some of the shareholders at local hui (community meetings), the Māori Land Court (MLC) amalgamated the lands in March 1974.

Friction arose over the following months, however, when one of the seven Court-appointed trustees, Graham Alexander (my maternal uncle), refused to join the other trustees in signing a forestry lease. He had become disturbed at how the trust was treating solely with one interested company, Carter Holt Farm and Forests Ltd, instead of calling for fresh tenders among the wider forestry industry. Also an owner, he and his siblings (including my late mother) held land shares on the very northern edge of the block near our own Ngaitewake-ki-uta tribal area.

In spite of considerable pressure on him to back down, Alexander held his ground, thus stalemating progress on the 99-year lease. For such legal documents to be valid, all trustees must sign. (Following Todorov, as cited by Stuart, these news events and their aftermath would be the 'disruption' and 'deterioration' phases of the Pakeha narrative.) After consultation with the Māori Land Court, an application was made to it by the secretary of the Trust, which succeeded in having Alexander removed. Alexander refused to submit, and at considerable personal legal expense, sought reinstatement onto 


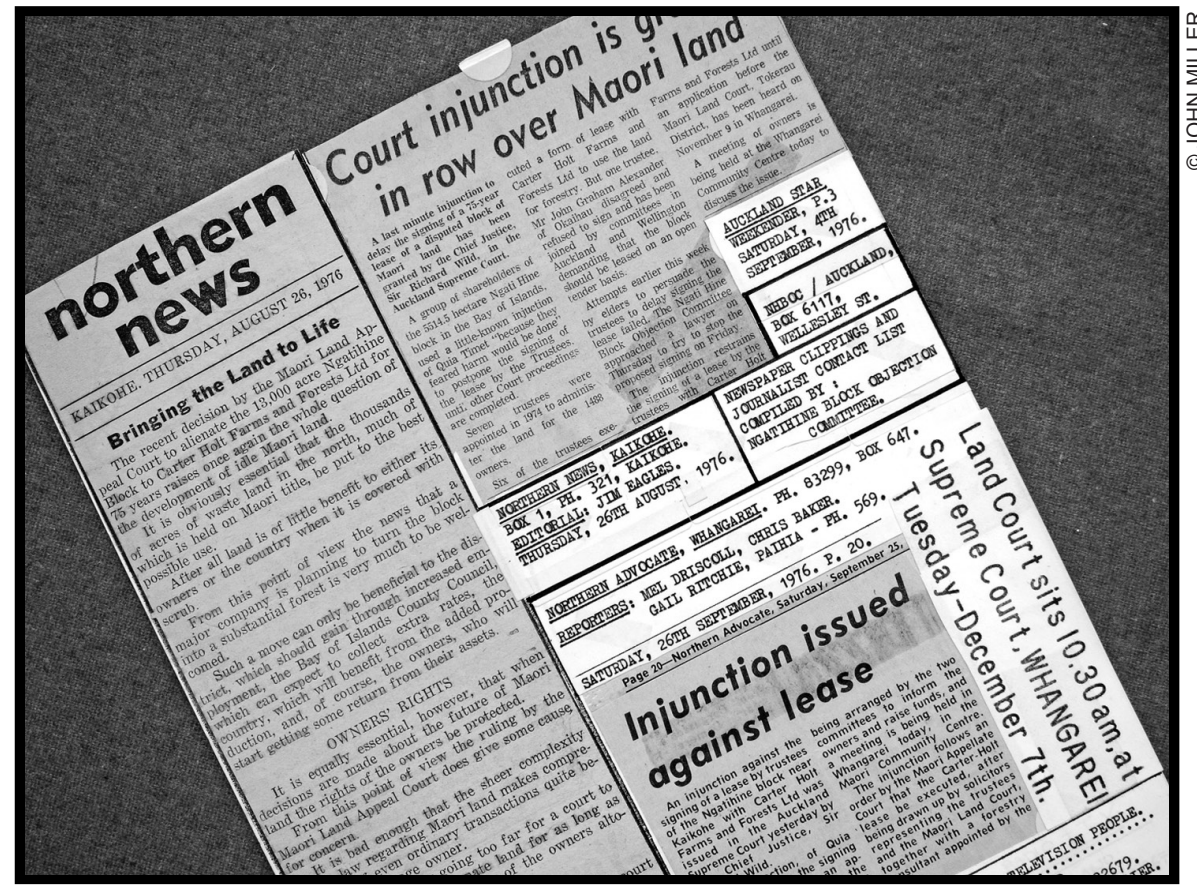

Figure 1: See-saw actions of Ngatihine court orders and appeals.

the trust board. By 1976, this delay was holding up the whole project but also led to many more of the ownership group going to Alexander's support as news of the proposed lease spread and people became more concerned about the loss of direct control over their land.

For the next couple of years, seesaw actions of court orders and appeals occurred between the two factions over Alexander's removal (Figure 1). Finally, a pivotal Supreme Court action in Auckland was heard before Justice Peter Mahon, in July 1978 (Court decisions, 1978). In his reserved decision later that month, Mahon ruled that the Māori Appellate Court (MAC) had acted without jurisdiction in altering the Trust deed to require execution of the Carter Holt lease by the Ngatihine trustees. He reinstated Alexander to the Trust (Judge sets aside, 1978).

\section{Historical ethos}

I became more deeply involved after the final MAC hearing, in August 1976, when I recall being most confused and perplexed by the judges' decision. 
I did not understand the historical ethos underlying the Māori Land Court's functions, but erroneously assumed that it was a neutral party not running its own agendas. I ingenuously believed that the wishes of the owners expressed to the Court would have been heeded, according to the principles of natural justice and the UN Declaration of Human Rights.

Following its judgment, I realised that the Court placed more store on facilitating 'development' than taking into account the wishes of the majority of aware shareholders who opposed the lease. Representations by some owners alleging inadequate consultation went unheeded by the judges. This Appellate Court decision could well have signalled a victory for the proponents of the whole Carter lease proposal and end of the road for Alexander's single-handed resistance to it. It is true that other shareholders had begun to rally around him and offer moral support. However, huge obstacles still remained if the lease signing were to be prevented.

1. Alexander's own legal initiatives had ended because of a lack of funds - there were no further actions holding up any lease.

2. A large number of the wider shareholding group remained either totally ignorant of or unfamiliar with the whole matter, there being scant media coverage of the issue, which could have alerted themthe August MAC session passed totally unreported (journalists were excluded by the Chief Judge, citing the commercial sensitivity of anticipated submissions by the forestry industry).

Given the above, I quickly realised that the shareholders who had come to support Alexander's stand needed to organise much more effectively and:

1. Rally ongoing support for him in his refusal to sign the lease,

2. Engage legal counsel to represent the shareholders' interests,

3. Search out and notify more shareholders and enlist their moral and financial support, and

4. Generate media interest in the case to reach yet more shareholders and enlist support from other Māori and Pakeha civil rights groups and the public at large.

This last task was extremely crucial and posed a number of difficulties. After the August court hearing, I recall experiencing a sense of hopelessness at how the issue was playing out almost completely under the radar of the media-one that was being treated as a peripheral minority matter, the subject of dry court reports which only scratched the surface (New evidence, 1976). 
The real issues underlying this arcane legal wrangle needed to be exposed if these aims were to be achieved.

I became quite angry at what I uncovered during my research into the foundations of the MLC system; none of this was adequately dealt with in the secondary education system with the result that most New Zealanders, including the journalists I was dealing with, were ignorant of these processes. The 1929 edition of JB Condliffe's A Short History of New Zealand used in schools as late as 1957, made no mention of the Native Land Court and its dire consequences at all.

That said, there seemed no real excuse for media ignorance of these contexts. The works of historians Alan Ward (1973, pp. 212-3), Keith Sinclair (1960, p. 143) and Keith Sorrenson (1956, pp. 185-7,191-2), which described the corrosive effects of the Native Land Court on the fabric of Māori social and economic life, were already in the public domain. However, this lacuna meant that I had to explain all this as best I could to journalists whom I approached. Over this period and beyond, I compiled various writings (quoting heavily from source material) that placed the Ngatihine case into a historical

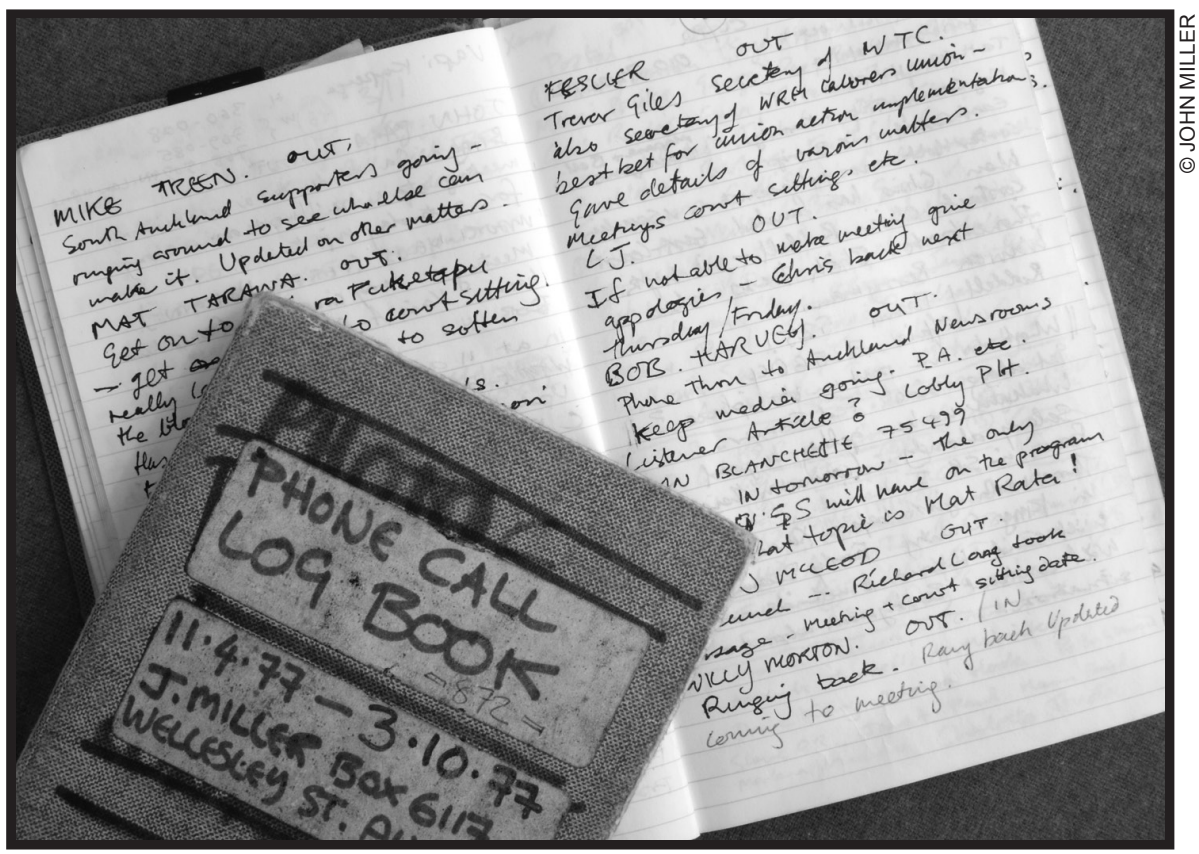

Figure 2: Detailed logs of Ngatihine telephone conversations. 
context of paternalistic, neo-colonial attitudes, of which mainstream society remained unaware or chose not to confront. These took the form of various papers written for seminars, contributions to non-mainstream newspapers and newsletters, booklets and some university sociology lectures.

I also began to keep a detailed log of phone call conversations (Figure 2), which has proved invaluable in compiling this account. During this immersion in the Ngatihine issue, I did not completely abandon my photographic activities but managed to photograph some of the protagonists at Court cases or hui and the land itself as well as other land disputes occurring elsewhere such as Bastion Point land occupation in Auckland (to frustrate an urban housing subdivision) and Raglan in the Waikato (to reclaim golf course land originally appropriated for a 2nd World War airfield).

Immediately following the August 1976 Appellate Court hearing, I joined forces with other shareholders in both Auckland and the North to establish a formal organisation, the Ngatihine Block Objection Committee (NHBOC) to support my uncle's position. ${ }^{2}$ I became the coordinator and spokesperson for the Auckland branch, which was chaired for the first 12 months by the former Māori Battalion captain, Dick Kake, a member of Ngatihine, resident in South Auckland. Funds were raised to engage a solicitor and further legal initiatives quickly followed. We gained some breathing space with a 'Quia Timet' Supreme Court injunction that froze the forestry lease proposal ahead of an application from the NHBOC to dissolve the trust (Court injunction, 1976).

Over the next 24 months I used my writing skills and media contacts to get our side of the case across wherever I could. An early achievement was getting TV2 to do a News at Ten report on the issue. David Beatson (a contact from recent Labour Party Conference days) put me in contact with Paul France and I spent a couple of days in the newsroom library, xeroxing off background material on the case for France to use. (At this time, I was most surprised to come across News at Ten's director Jan Wharekawa in the newsroom, Māori women on the production side of TV being almost unheard of in those days.) The News at Ten item went to air on August 20 and dealt purely with the legal angles. No historical-social perspectives were investigated-I was not yet fully aware of these so was unable to brief France on them (he also had tight time constraints on his report).

Throughout the period of the dispute, the daily newspapers generally stuck to reporting it as a series of courtroom actions without delving deeper (Ngatihine Trustee, 1977) They did not, for example, question how these 


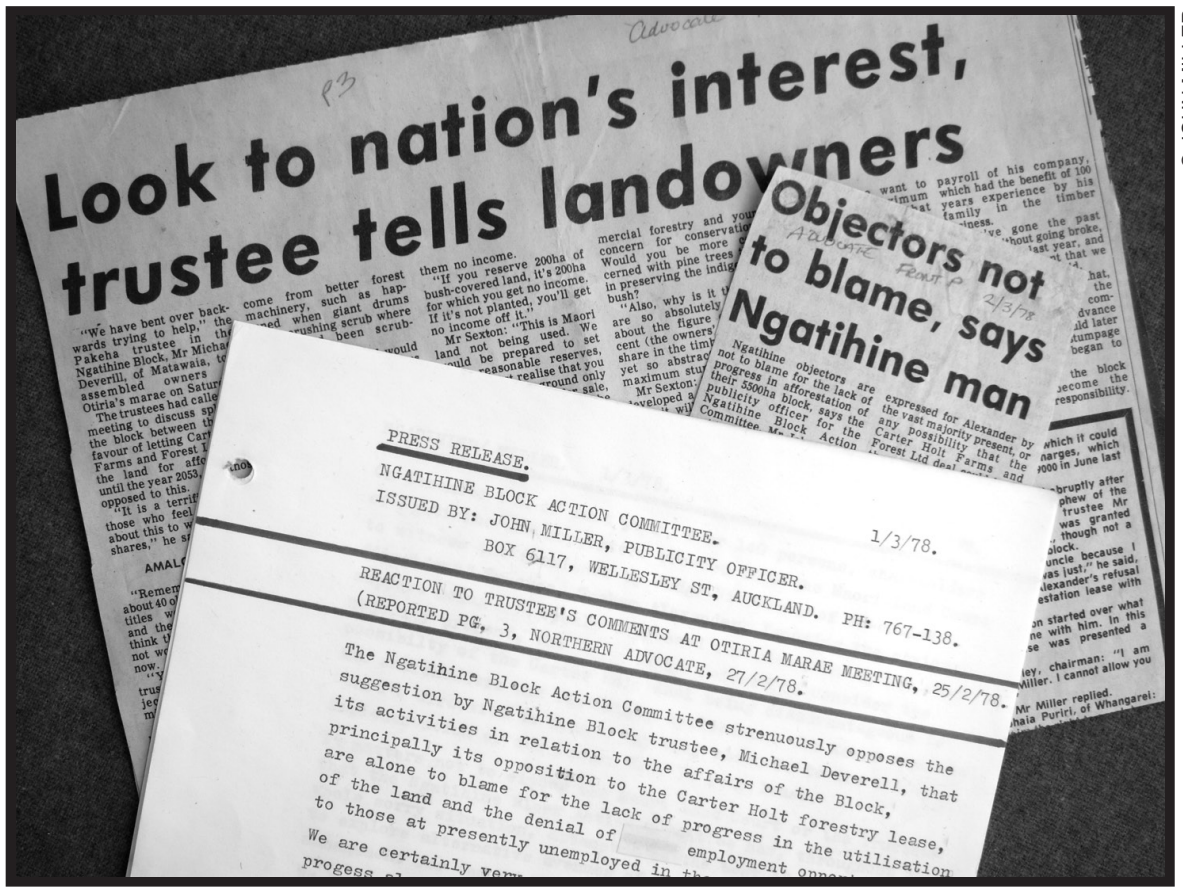

Figure 3: Mainstream media coverage took for granted the status quo of the Pakeha narrative.

lands came to need trustees appointed to administer them in the first place, or why the land's owners had become so fragmented and disorganised. Nor did they show how a Court was able to enforce a course of action over land while opposed by many of its owners - a situation that Pakeha land owners would have found intolerable.

\section{Māori narrative of colonial disruption}

To directly confront these questions, the Māori narrative of colonial disruption and dispossession of the tribal estate needed to be acknowledged and used to contextualise the reportage on the dispute (Figure 3). Instead, journalists, ignorant of these factors, took for granted the status quo of the Pakeha narrative (ie. Maori lands are ipso facto unproductive and under the control of incompetent and disinterested owners). They just reported court proceedings and reactions of a recalcitrant trustee and obstructive shareholder groups, reflecting a view that these were disruptions that held up progress and beneficial economic development (Look to nation's interest, 1978). 


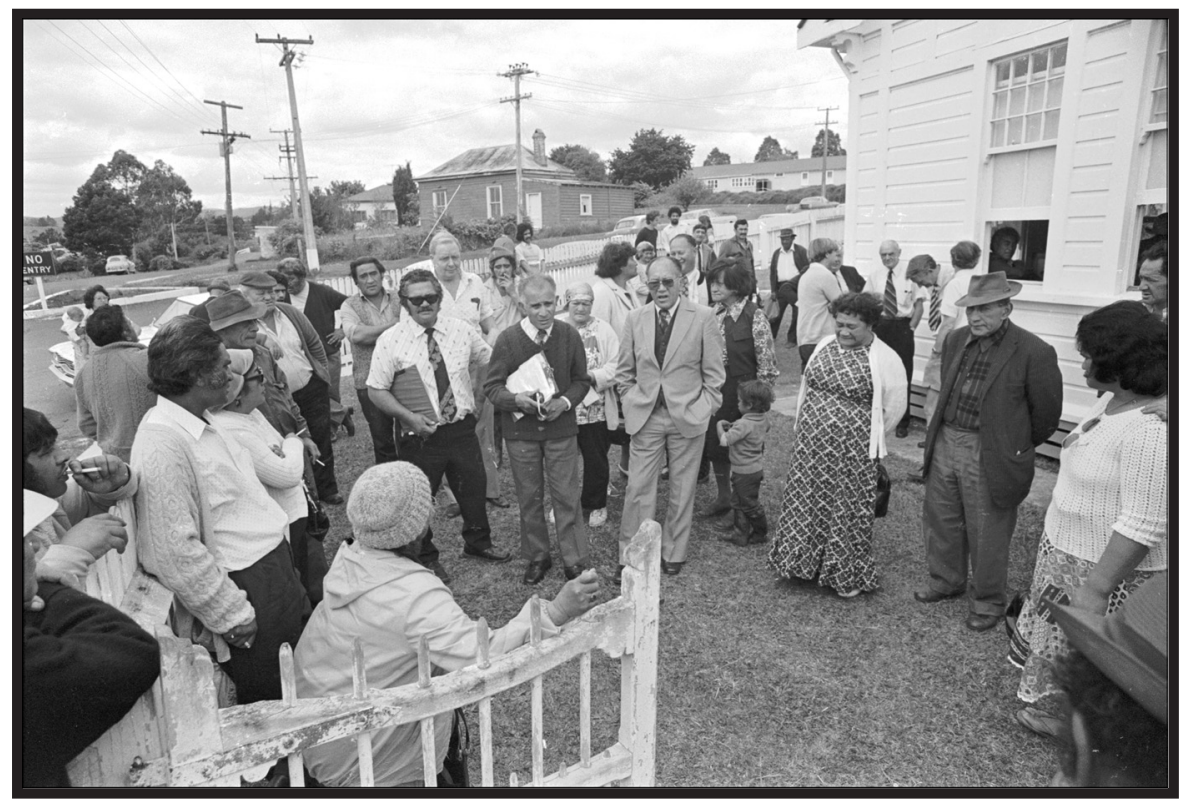

Figure 4: Ngatihine shareholders hold an impromptu meeting after a Māori Land Court session. Kawakawa, Northland, 14 November 1977.

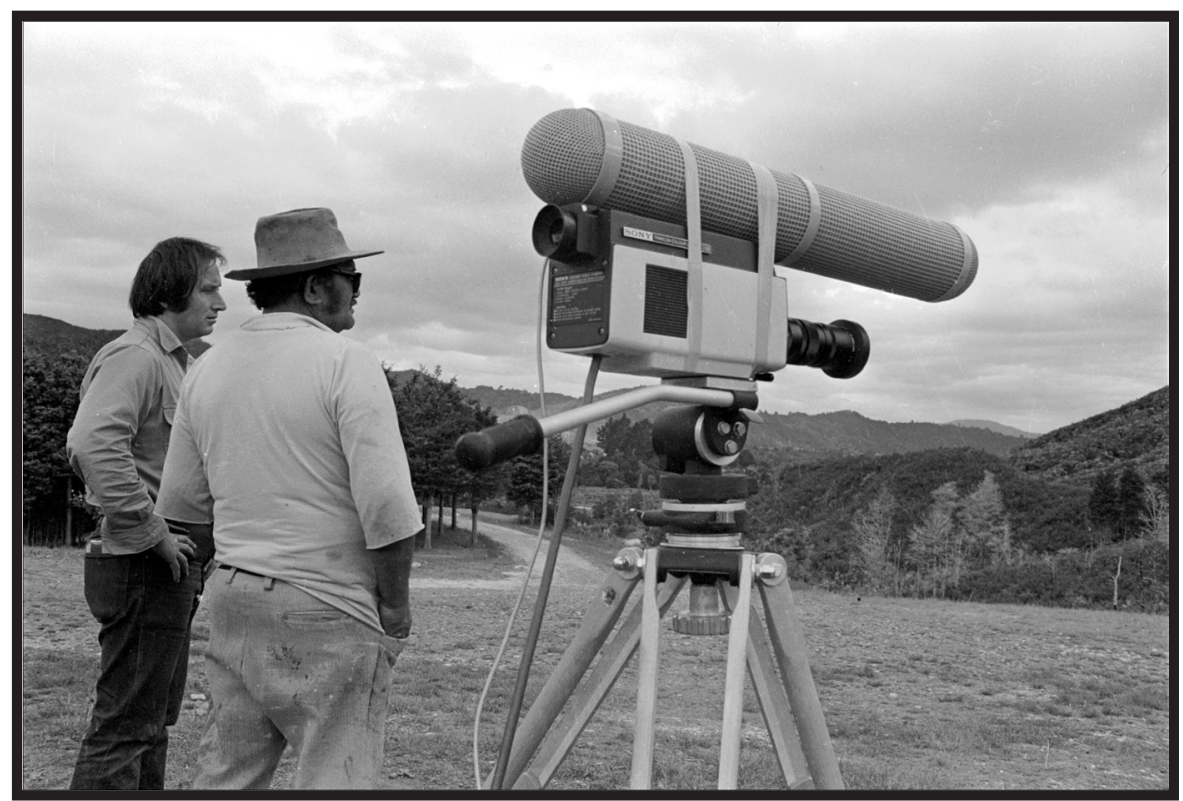

Figure 5: Videographer Darcy Lange about to interview local NHBOC committee member/shareholder, Motatau Shortland. Matawaia Marae, November, 1977. 
INVESTIGATIVE JOURNALISM

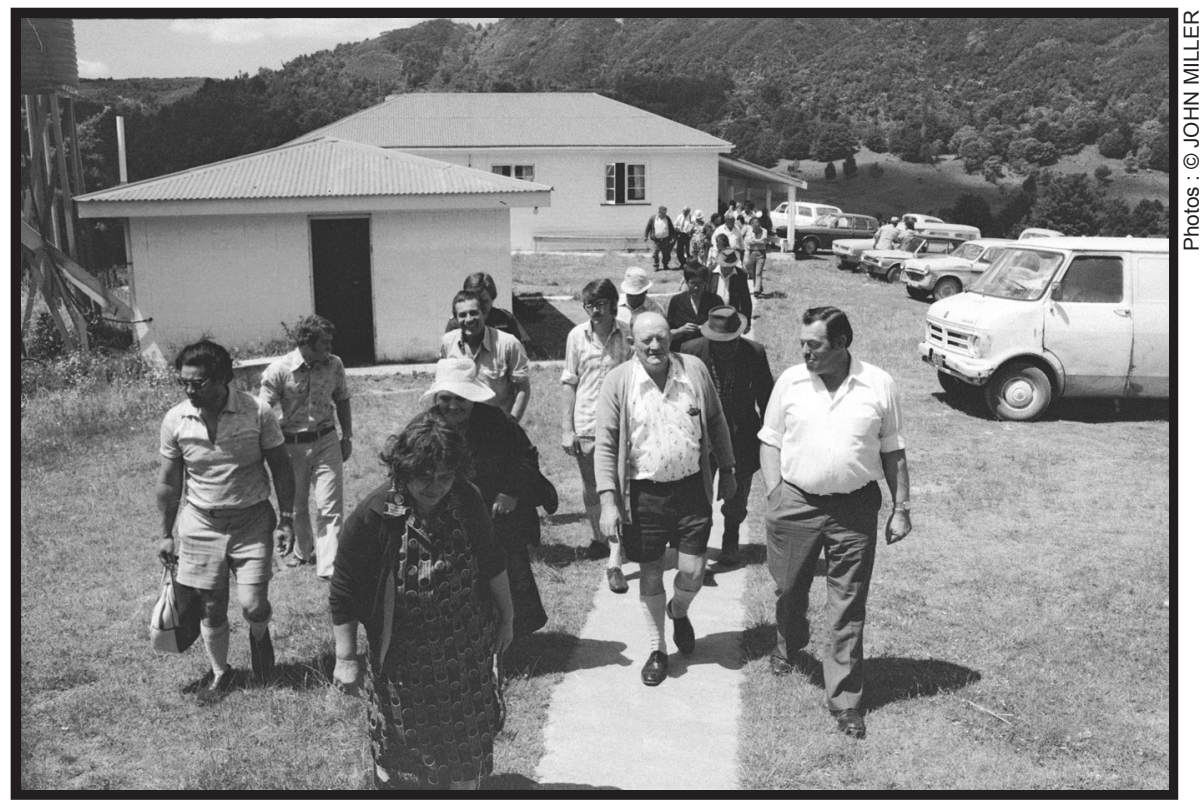

Figure 6: Shareholders and supporters arrive for a Ngatihine Block Action Committee meeting. Matawaia Marae, 24 June 1978.

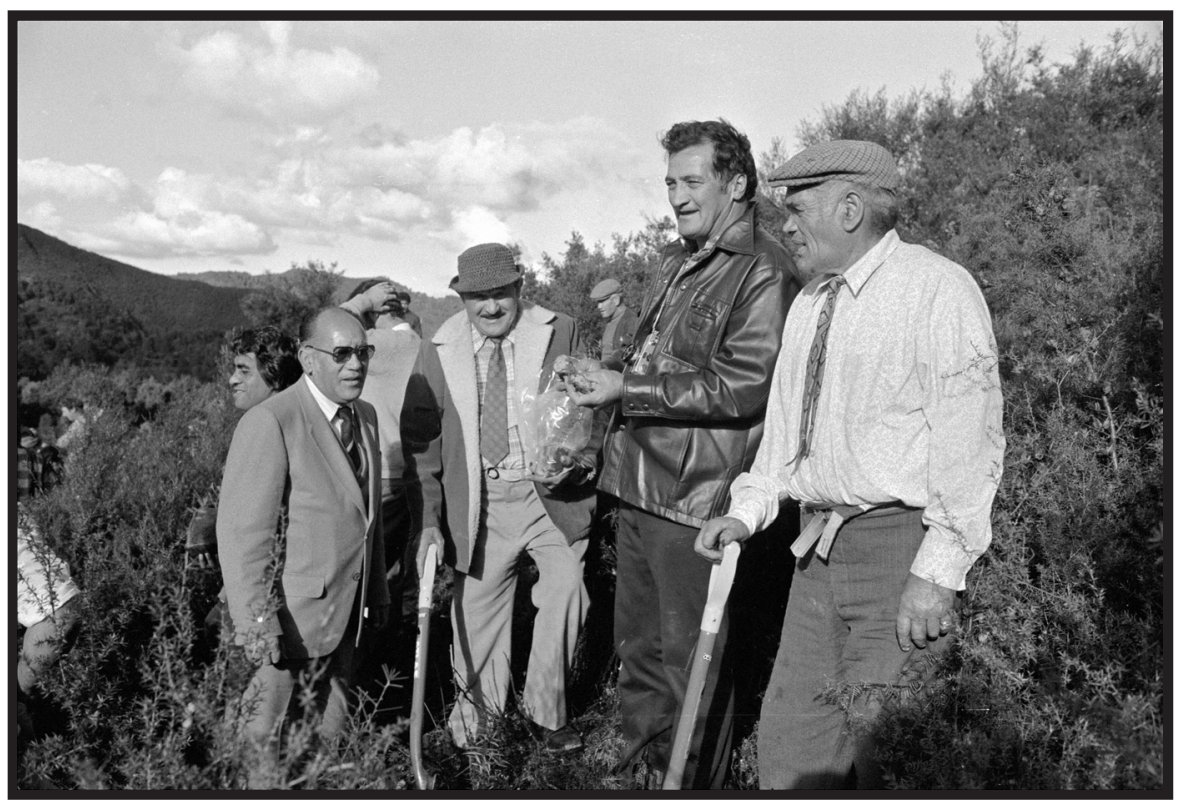

Figure 7: The first ceremonial forest planting at Matawaia Marae, late 1981. From left: Dick Kake, Wiremu Coffey, Graham Alexander and Witari Peihopa. 
Coverage concentrated on the minutiae of Alexander's ongoing dispute with the trustees and little appeared reflective of fundamental principals that motivated the dissenting shareholders. (Forestry scheme, 1976). For some, the open tender matter had evolved in to the greater issue of regaining control of the land itself.

However, the Northern Advocate did publish two articles on my organising activities and the Māori narrative I was trying to bring to more prominence (The Māori struggle; Researcher discusses, 1978). It extensively reported one of the trustees meetings where shareholders were upset at restrictions on speaking rights (I was one of those silenced) while Carter Holt representatives spoke unimpeded, and initial attempts to prevent journalists reporting the gathering produced angry reactions from local elders and comments on the desirability of their presence on the marae (Press not; Man angry; Press pose, 1978).

One journal that early on bucked the prevailing trend was Jim Eagles' Northern News in Kaikohe. Having been supplied by Alexander, in 1976, with a box of documents about the case, Eagles took a more critical perspective in an editorial on the MAC's decision. However, the article took the the breach of personal property rights angle and did not delve into the historical narrative itself (Bringing the land, 1976).

By the first part of 1977, I had begun my personal research, and from then on, added material from these to some of the 15 press releases I issued over a period of 23 months. The background piece that the late Warren Berryman wrote for National Business Review (NBR) incorporated much of my information in his article. This was unwelcome publicity for Carter Holt and its spokesman Richard Carter was reported to be '... most upset if anything were published at this time' (Berryman, 1977).

If most of the mainstream was taking a narrow approach, the alternative press was more searching. The Socialist Action League's publication, Socialist Action, printed in 1977 a number of critical articles about the case, in one instance, actually recycling some of my historical perspectives from Berryman's NBR article (Ngatihine land, 1977). It also ran an edited version of a paper on historical processes and Māori land that I wrote for a Public Service Association race relations seminar, later republished almost verbatim by the PSA Journal (The great Māori, 1977). Using my research, Socialist Action also began to examine more broadly the forestry sector's leasing of 
thousands of hectares of other Māori land blocks elsewhere in the country (Forestry giants, 1977).

The Auckland University Students Association (AUSA) newspaper Craccum also printed articles referencing historical factors, two written by MA political studies student Virginia Shaw and one that I wrote myself(Shaw, 1977; Miller, 1978).

I was also invited to relate the historical narrative underlying the case in a guest article for the industry sector magazine Forest Industry Review, then edited by Gary Taylor. This appeared alongside one by Carter Holt chairman Alwyn Carter, which predictably presented his justifications for his company's compliance with the directions of the Māori Appellate Court and his characterisation of our shareholders group as 'disturbing elements' (Māoris say no, 1978).

The increasing number of press clippings featuring the case also became valuable for informing the Ngatihine landowners of developments. I would recut the articles to fit a page format for xeroxing and

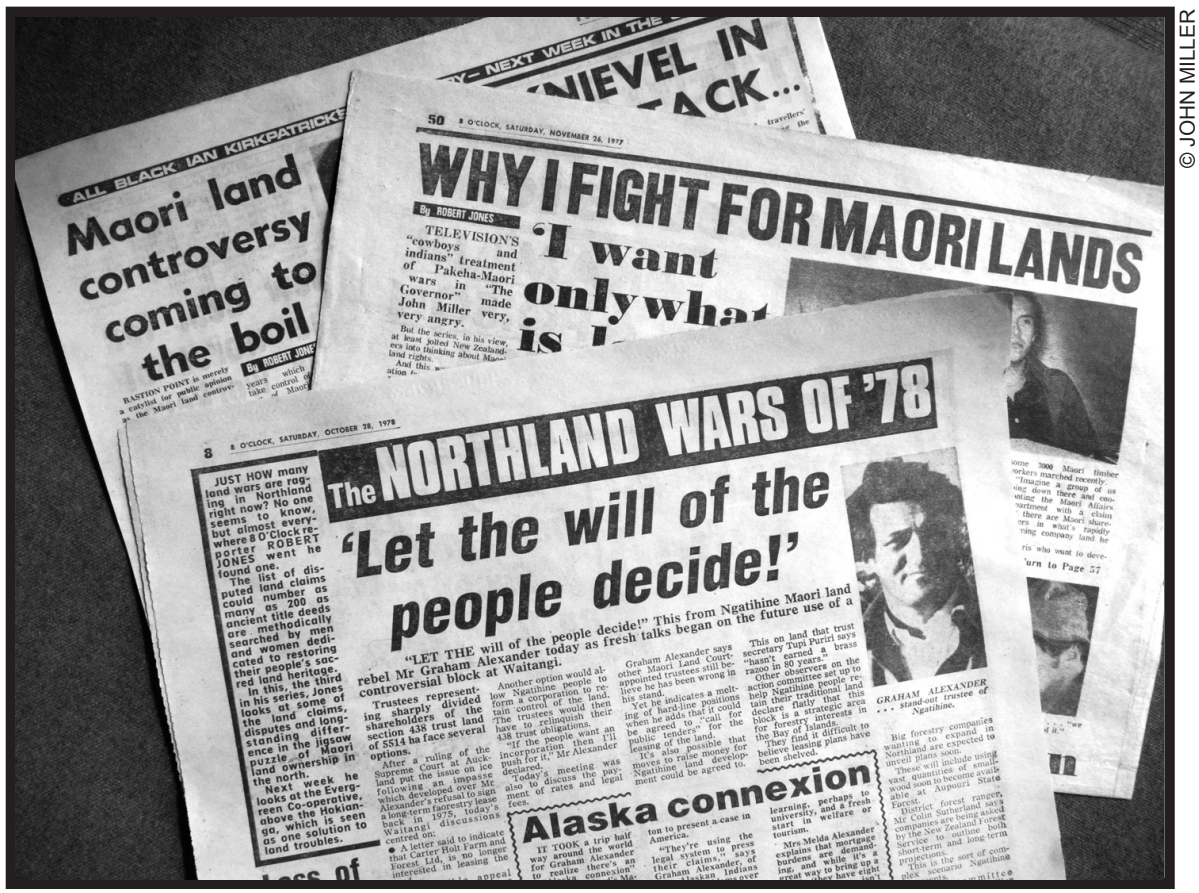

Figure 8: A compilation of Robert Jones articles in the $8 \mathrm{O}^{\prime} \mathrm{Clock}$. 


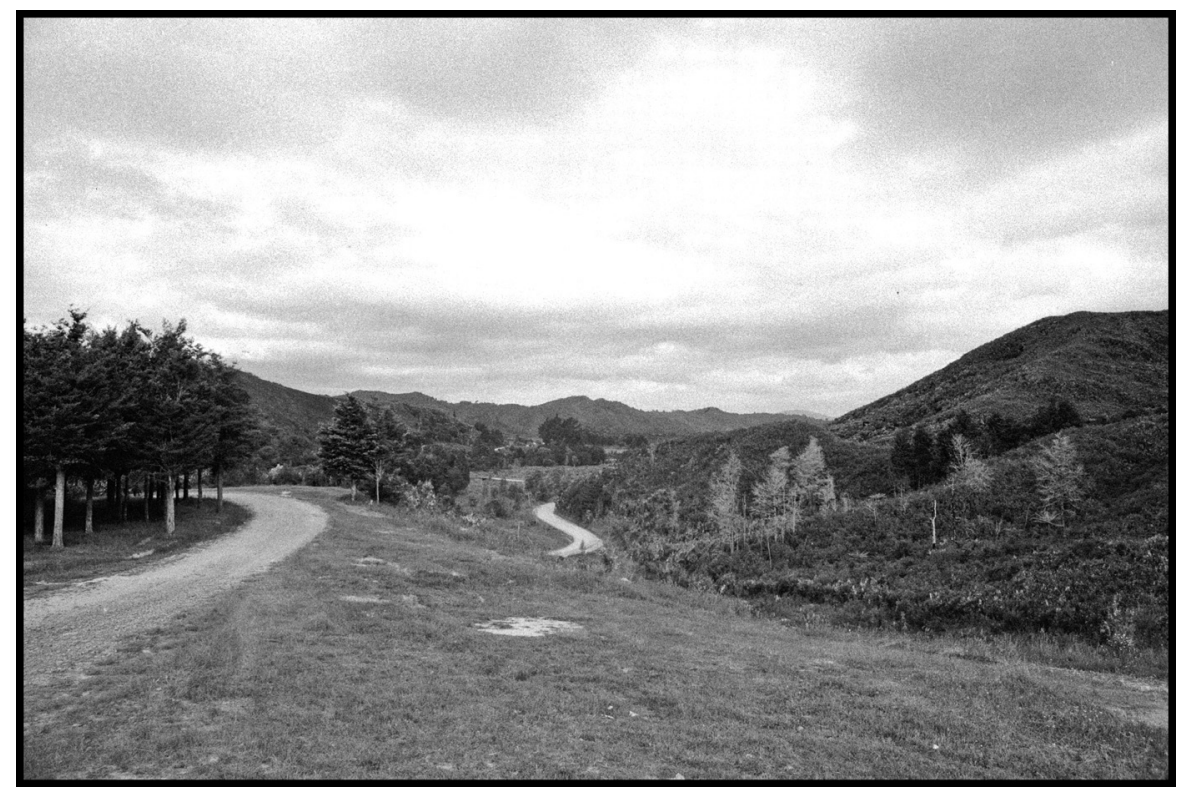

Figures 9a and 9b: Matawaia Marae vista looking east, 1977. Below: Figures 10a and 10b: The same vista 31 years later in 2008.

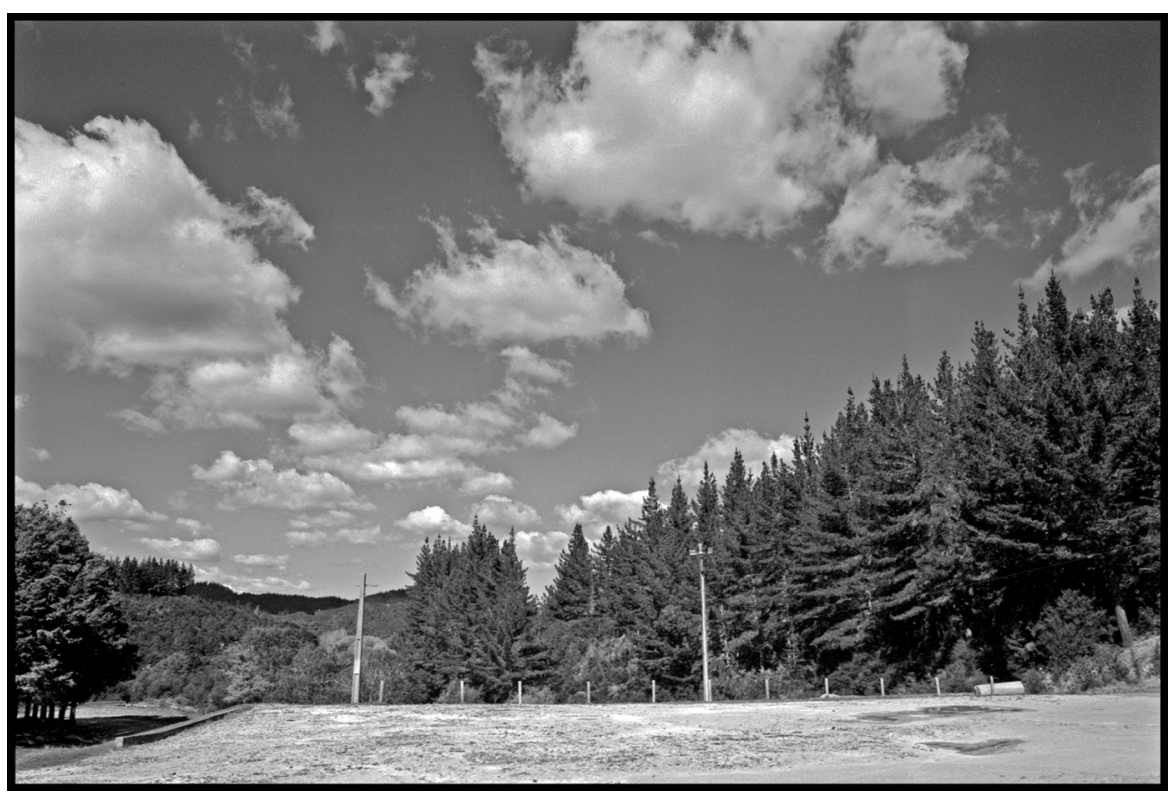

188 PACIFIC JOURNALISM REVIEW 17 (1) 2011 


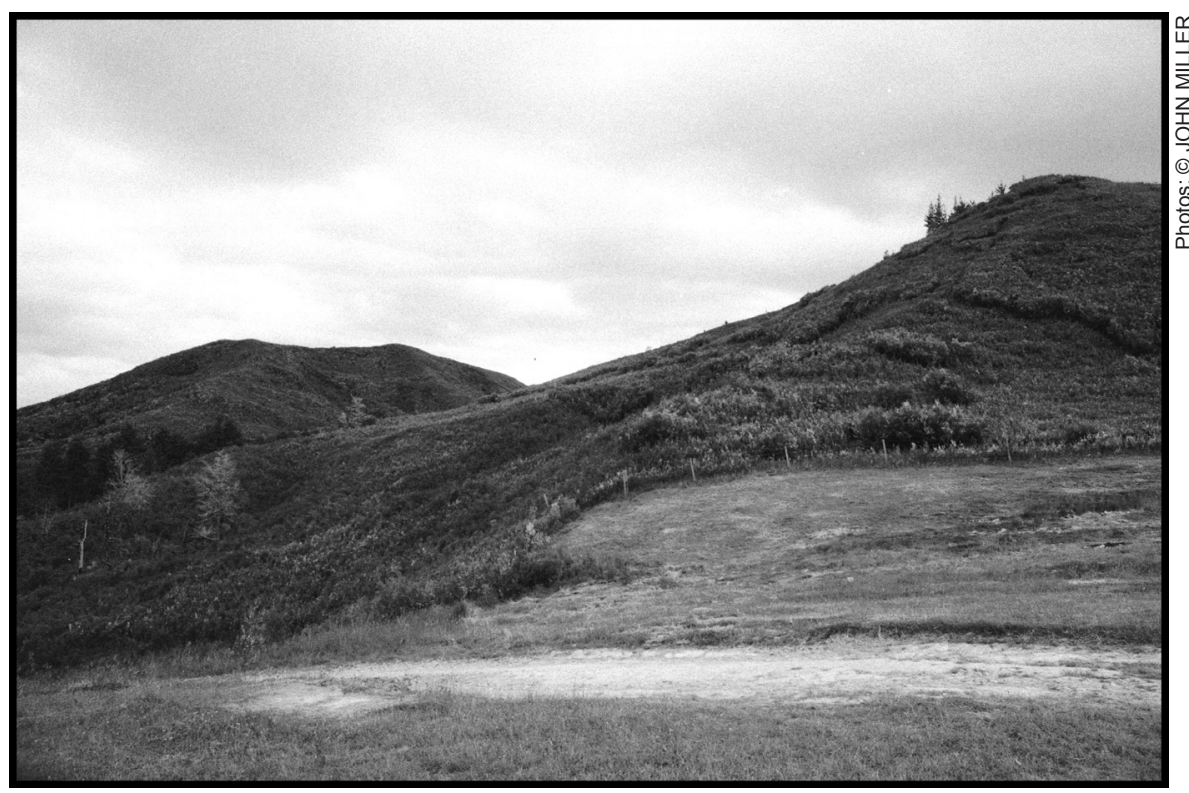

Title page 169: Original forest cover vista, Ngatihine Block, southern section, November 1977.

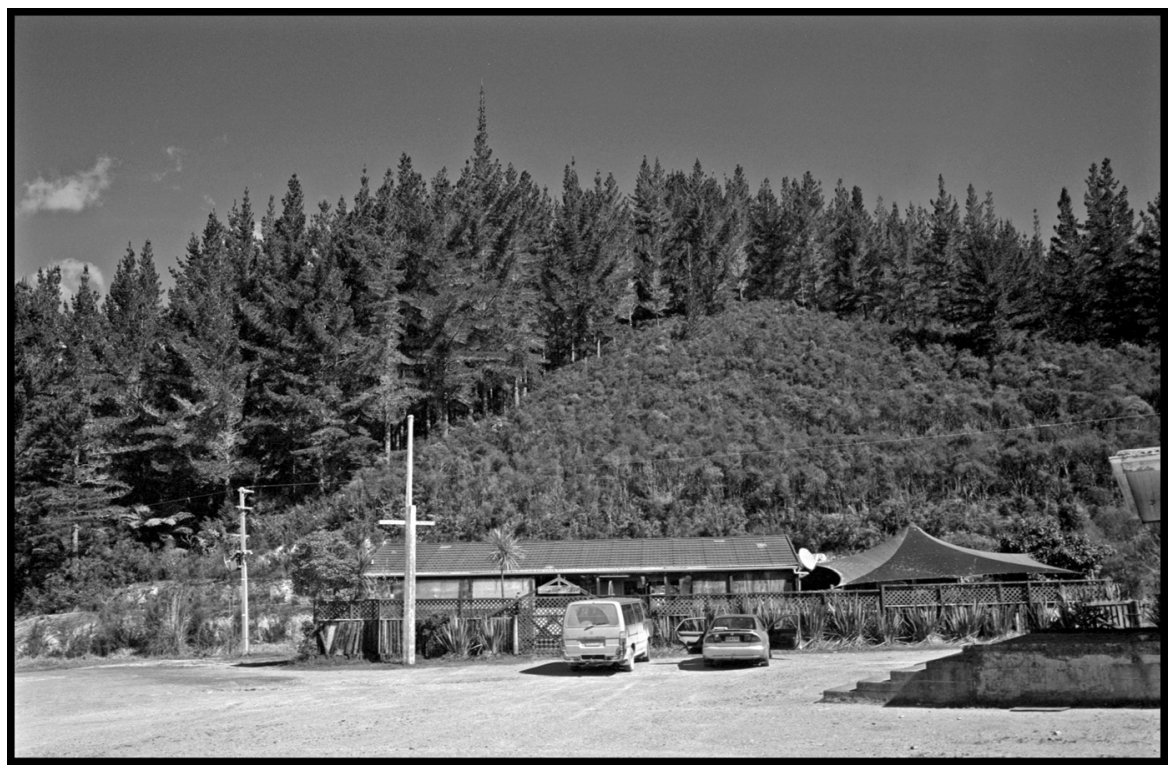

PACIFIC JOURNALISM REVIEW 17 (1) 2011189 
distribute them in mail outs (Figure 1). One small article I wrote for the November 1977 Epicentre News circular had unexpected consequences (Miller, 1977). It was spotted by $8 O^{\prime}$ Clock journalist Robert Jones who quickly contacted me to learn more of our situation. Jones came from a working class background and knew about injustice and dispossession. He empathised with Alexander's underdog position confronting inflexible bureaucracy and big money (Figure 8). In a series of articles extending over several months, he covered Alexander's stand opposing the lease, my organising activities and historical researches and the Taranaki videographer Darcy Lange's Māori land video project, some of which covered the Ngatihine case (Peters, Miller, 2008, pp. 144-5).

Jones' investigations culminated in his four-part series 'the Northland Wars of 78', which detailed his explorations of several land issues (including Ngatihine) during a trip around Northland (Jones, 1978). At that time, the $8 O^{\prime}$ Clock's management was considering expanding its scope beyond that of just a sports results paper and Jones' articles were indicative of the material an expanded social section would contain, especially if envisaged evolution into a full on Sunday paper had ever taken place (R. Jones, personal communication, October 2008).

In this media review, one has to place the Ngatihine case into the wider news environment of the times. Concurrent with this particular issue, a number of other struggles in which I had some involvement, were also occupying the media's attention. Disputes over Bastion Point, the Raglan golf course and the Te Hapua 42 Māori land/forestry project near Cape Reinga were making it a crowded field (Te Hapua 42, 1977). Some commentators independently took up issues I was pressing: Dr Ngatata Love and Rev Hone Kaa expressed alarm over the wholesale leasing of Māori Lands by forestry companies and other researched articles on the inadequacies of the Māori Land Court system subsequently also later appeared (Kaa, 1978; Love, 1980; Reynolds, 1982).

\section{Concluding comments}

All this ferment provided a background where Māori land issues were becoming more prominent and emphasised the need for members of the media to deal with them in more depth. Although most of the journalists I dealt with were unfamiliar with the Māori narrative and only a few chose to investigate that direction, some became very sympathetic and interested in our case as 
they recognised that something was occurring here that they saw as being fundamentally unjust and unfair. The reports that they wrote or broadcast did play a part in raising awareness among the Ngatihine shareholders and informing a supportive public. Some actually stepped outside their neutral reporting role and helped us directly, like radio journalist Colin Feslier at $1 \mathrm{ZN}$ who put me on to officials of the Whangarei Trades Council. This led to the placing of a union 'green ban' on the block-reported of course by $1 \mathrm{ZN}$ (Unions intend, 1977).

Given the environment of the day, in which the present collection of Māori radio stations, print media and TV channels were entirely absent, I believe that our efforts achieved some success in shaping the media's response to the Ngatihine issue. I will leave it to others much more qualified than me to comment on whether the media as a whole have improved their sensitivity to bicultural matters in the intervening three decades.

Following the 1978 Mahon decision, a compromise in the Ngatihine dispute was achieved in 1980, after personnel changes in the Māori Affairs Department and Māori Land Court. This saw a reconstitution of the Ngatihine Trust, where a Principal Trustee was appointed along with number of Advisory Trustees selected from shareholders and locals who had been on both sides of the earlier dispute. After a new round of negotiations with the forestry industry, a 33-year lease was signed on 1 October 1981, which contained significant improvements and enhancements over that first proposed in 1974 (Lease signing, 1981). The present-day Ngati Hine Trust has evolved into a well-run entity, which administers kiwifruit farms and a housing portfolio as well as the original forestry block on which the first rotation is now being harvested (Prayers for, 2009; Ngati Hine Forestry Trust).

\section{Notes}

1. Figures are extracted from the author's original documentation and phone log records.

2. The name was changed to Ngatihine Block Action Committee (NHBAC) on 3 November 1977.

\section{References}

Abel, S. (2010, March 8). A question of balance. The New Zealand Herald. Retrieved on 23 November 2010, from: www.nzherald.co.nz

Berryman, W. (1977, July 1). Carter Holt hits a knot and Māori land chips could fly. National Business Review, p. 8. 
Bringing the land to life. (1976, August 26). Northern News.

Condliffe, J.B. (1929). A short history of New Zealand. Christchurch: I. M. Isitt. Court decisions challenged. (1978, July 4). The New Zealand Herald.

Court injunction is granted in row over Māori land. (1976, September 4). Auckland Star Weekender, p. 3.

Forestry giants swallow Māori land. (1977, November 4). Socialist Action, p. 1. Forestry scheme stalled again. (1976, September 23). Northern News.

Jones, R. (1977, November 19). Māori land controversy coming to the boil. 8 O'Clock, p. 7.

Jones, R. (1977, November 26). Why I fight for Māori Lands. 8 O'Clock, p. 50 Jones, R. (1977, December 23). Māori land fight, it's all on film! $8 O^{\prime}$ Clock, p. 30. Jones, R. (1978, October 28). Let the will of the people decide. $8 O^{\prime}$ 'Clock, p. 8. Judge sets aside forestry lease decision. (1978, July 29). The New Zealand Herald. Kaa, H. (1978, December 13). Land bill bad for us, says Māori missioner. Auckland Star.

Kawharu, I. H. (1977). Māori land tenure: Studies of a changing institution. Oxford: Clarendon Press.

Lease signing ends saga of 50 years. (1981, October 2). Northern Advocate. Love, N. (1980, January 29). Another land grab's coming. NZ Truth, p. 2.

Look to nation's interest, trustee tells landowners. No planting, just mounting debts for Ngatahine (sic) block. (1978, February 27). Northern Advocate, p. 3.

Man angry over press ban. (1978, February 28). Northern Advocate.

Maori Affairs Act 1953/94, s. 438 (5).

Māoris say no to lease. (1978, April). Forest Industries Review, p. 4.

Miller, J. (1977, November). Stop Māori land grab. Epicentre News 11, p. 7.

Miller, J. (1978, June 19). New Māori land wars. Craccum, p. 10.

Morgan, A. (2009). Media diversity: The challenge of 'doing it better'. Pacific Journalism Review, 15(1), 93-113.

New evidence in appeal case. (1976, June 24). The New Zealand Herald.

Ngati-Hine Forestry Trust. Retrieved on 12 April 2011, from www.ngatihine.maori. nz/main.htm

Ngatihine land grab blocked. (1977, July 10). Socialist Action, p. 12.

Ngatihine trustee dismissed again. (1977, December 7). The New Zealand Herald.

Peters, G., \& Miller, J. (2008). Māori Land Project. In Vicente, M. (Ed), Darcy Lange: Study of an Artist at Work ( pp. 143-155). Auckland: Ikon/Govett Brewster Art Gallery.

Prayers for an auspicious pine forest harvest. (2009, March 13). Northern Advocate, p. 3.

Press not welcome. (1978, February 25). Northern Advocate.

Press pose fresh problem on marae. (1978, March 2). Northern Advocate.

The great Māori land swindle. (1977, September). Public Service Journal.

The Māori struggle: Mana v officialdom. (1978, February 18). Northern Advocate.

Researcher discusses Māori land issues at Dargaville meeting. (1978, July 8).

Northern Advocate. 
Reynolds, T. (1982, March 20). Court muddle threatens Māoris' land. The New Zealand Herald, p. 1.

Sinclair, K. (1960). A history of New Zealand. Auckland: Penguin.

Shaw, V. (1977, June 27). Whose land...whose decision? Craccum, pp. 18-19.

Sorrenson, M.P.K. (1956). Land purchase methods and their effect on Māori population, 1865-1901, Journal of the Polynesian Society, 65(3), pp. 183-199.

Stuart, I. (2002). Māori and mainstream: Towards bicultural reporting. Pacific Journalism Review, 8, 42-58.

Te Hapua 42: Court stalls deal on Māori land. (1977, August 13). The New Zealand Herald, p. 1.

Unions intend to block forest project. (1977, December 20). The New Zealand Herald. Universal Declaration of Human Rights 1948, 17 s2. United Nations.

Ward, A. (1973). A show of justice, racial 'amalgamation' in C19th New Zealand. Auckland: Auckland University Press/Oxford University Press.

Webster, S. (1975). Cognatic descent groups and the contemporary Māori: A preliminary reassessment. Journal of Polynesian Society, 84(2), pp. 121-152.

John Miller (Ngäpuhi) is an independent photojournalist who has chronicled more than four decades of social and political dissent in Aotearoa/New Zealand. He wishes to acknowledge and thank Dr David Robie and the Pacific Media Centre of AUT University for a generous grant and support for this research project. He also offers his deepest gratitude to Dr Geraldene Peters for her editing skills and patient guidance and support which have been crucial in bringing this project to fruition. Dr Peters initiated an interactive digital timeline incorporating photographs and ephemera associated with the case study. This was demonstrated at the Media, Investigative Journalism and Technology (MIJT) conference at AUT University in December 2010 and it is planned to extend the research through an online presence in the near future.

Finally, the author would like to pay tribute to all those who were part of this story and have since passed on; and to all the people of Ngatihine (and their many outside supporters) who joined with John Miller's late uncle in bringing this land dispute to a happy and successful conclusion.

Na reira, haere atu rā koutou, moe mai rā i roto i te moenga roa o o tūpuna mātua. Ahakoa, kua wehe atu koutou, kei te ora tonu te kaupapa ranga tira nei. Nga mihi nui ki te iwi o Ngatihine whānui, na koutou tōku matua i tautoko $i$ roto $i$ tenei āhuatanga.

taiamai@hotmail.com 